\title{
Lack of effect of nitrates on exercise tolerance in patients with mild to moderate heart failure caused by coronary disease already treated with captopril
}

\author{
Siegfried Wieshammer, Martin Hetzel, Jürgen Hetzel, Matthias Kochs, Vinzenz Hombach
}

\begin{abstract}
Objective-To test the hypothesis that the addition of nitrates improves exercise tolerance in patients with heart failure caused by coronary artery disease already treated with an angiotensin converting enzyme inhibitor and diuretics. Design-Randomised, double blind, placebo controlled, 16 week treatment periods.
\end{abstract}

Setting-Outpatient clinic at a university hospital.

Patients-54 patients with previous myocardial infarction, symptoms of mild to moderate heart failure, left ventricular ejection fraction below $40 \%$, no exerciseinduced angina or electrocardiographic signs of ischaemia. Four patients in the nitrate group $(n=24)$ and one patient of the placebo group $(n=25)$ were withdrawn from the study.

Intervention-After the patients had been on constant doses of captopril and diuretics for at least 2 weeks, they were randomised to receive a target dose of $\mathbf{4 0}$ mg isosorbide dinitrate twice daily or placebo in addition to the continuation of captopril and diuretics.

Measurements-Bicycle exercise tests with measurement of gas exchange were carried out before randomisation and after 1, 6, 12, and 16 weeks of the double blind treatment. The change in peak oxygen uptake from control to week 16 was prospectively defined as the main outcome measure.

Results-The increase in peak oxygen uptake from before randomisation tended to be greater in the placebo group (before randomisation $17.4(3.4) \mathrm{ml} / \mathrm{min} /$ kg) than in the nitrate group (before randomisation $17 \cdot 1(3.5) \mathrm{ml} / \mathrm{min} / \mathrm{kg})$ after 12 weeks (mean increase 1.1 (2.7) v 0.0 (2.7) $\mathrm{ml} / \mathrm{min} / \mathrm{kg}, \mathrm{p}<0.12)$ and 16 weeks $(1.7$ $(3.0) v 0.3(2.6) \mathrm{ml} / \mathrm{min} / \mathrm{kg}, \mathrm{p}<0.14)$ of treatment.

Conclusion-The addition of nitrates to a baseline treatment consisting of captopril and diuretics did not improve exercise tolerance.

(Br Heart f 1993;70:17-21)
Angiotensin converting enzyme inhibitors are now widely used for the treatment of chronic congestive heart failure, mostly in combination with diuretics. ${ }^{1}$ The long-term efficacy of nitrates in congestive heart failure has been a matter of controversy ${ }^{2}{ }^{3}$ but some studies suggested that nitrates given either as the sole vasodilator or in combination with other vasodilators are useful in this condition. ${ }^{4-6}$ The mechanism of action of nitrates differs from that of converting enzyme inhibitors. Nitrates are direct vasodilators. Their vascular effects are claimed to be mediated by their transformation into nitric oxide. Endothelium derived relaxing factor was recently identified as nitric oxide. ${ }^{7}$ Nitrates may therefore be seen as prodrugs mimicking endothelium dependent endogenous vasodilatation. Converting enzyme inhibitors produce vasodilatation by removing circulating and local angiotensin II. Further, these agents increase concentrations of vasodilatory kinins and prostaglandins and lessen cardiac sympathetic drive. These differing and potentially complementary actions suggest the possibility of a beneficial drug interaction in congestive heart failure. Because nitrates act to improve coronary artery blood flow, supplementing the effects of converting enzyme inhibitors by nitrates seems especially appealing when coronary artery disease is the underlying cause of the heart failure. Captopril was shown to increase coronary reserve and may potentiate nitrate induced coronary dilatation. ${ }^{89}$ Animal data suggest that converting enzyme inhibitors, such as captopril, that contain the sulphydryl group might have a greater coronary vasodilator potency than those that do not. ${ }^{10}$ We studied the long-term effect of isosorbide dinitrate on exercise tolerance in patients with congestive heart failure secondary to coronary disease and without evidence of ischaemia who were already being treated with captopril and diuretics.

\section{Patients and methods}

PATIENTS

Patients with a history of at least one myocardial infarction more than 3 months before the study and with symptoms of congestive heart failure were considered eligible if they met the 
following criteria: (a) age 30-70 years, (b) left ventricular ejection fraction below $40 \%,(c)$ exercise tolerance $40-120 \mathrm{~W}$ on a pre-entry exercise test, (d) limitation of exercise tolerance by dyspnoea or fatigue, $(e)$ no exerciseinduced angina or electrocardiographic signs of ischaemia, $(f)$ normal lung function, and $(g)$ no valve disease except for mild mitral regurgitation. The exclusion criteria were as follows: (a) contraindications to converting enzyme inhibitors or intolerance to nitrates, (b) limitation of exercise tolerance for any reason other than dyspnoea or fatigue, $(c)$ arterial hypertension, (d) standing systolic blood pressure below $100 \mathrm{~mm} \mathrm{Hg}$, (e) history of transluminal coronary angioplasty or coronary artery surgery during the previous 3 months, $(f)$ need for antiarrhythmic agents other than amiodarone, $(g)$ history of poor drug compliance, $(h)$ significant concomitant disease. The study was approved by our institutional ethics committee. Informed written consent was obtained.

\section{STUDY DESIGN}

Patients meeting the above criteria were entered into the run-in phase at the beginning of which all antianginal drugs were stopped. The patients were given a baseline treatment consisting of captopril and diuretics. The captopril dose was increased over 4 days to a target dose of $25 \mathrm{mg}$ twice daily which was approached as close as the blood pressure permitted. Only four of the randomised patients took less than the target dose (12.5 mg twice daily). The dosage of the diuretic was optimised. Patients who had been taking other converting enzyme inhibitors were switched to captopril. Those who had been treated with digoxin before entering the study continued taking digoxin at a constant dose throughout the study. After the patients had been on constant doses of captopril and diuretics for at least 2 weeks, the run-in phase ended with two bicycle exercise tests with measurement of gas exchange. The tests were carried out 2-4 days apart. The second test was taken to provide the prerandomisation control values. ${ }^{11}$

The 16 week double-blind treatment phase then followed. The patients were randomised to received either a target dose of $40 \mathrm{mg}$ isosorbide dinitrate twice daily or placebo in addition to continuation of captopril and diuretics at constant doses. The study drug was taken at 8 am and $4 \mathrm{pm}$, the diuretic at 8 am, and captopril at 8 am and $6 \mathrm{pm}$. The drugs were taken according to this schedule on study days. Exercise testing was carried out $90-120$ minutes after ingestion of the morning doses. The patients were seen 1,6 , 12 , and 16 weeks after randomisation. At each visit the New York Heart Association functional class was determined and a bicycle exercise test with measurement of gas exchange was carried out. All the patients were followed up by the same physician and in the same manner.

Laboratory tests including blood chemistry and blood cell count were carried out at entry; before randomisation; and at weeks 1 , 6 , and 16 on randomised medication.

\section{EXERCISE TESTING WITH MEASUREMENT OF RESPIRATORY GAS EXCHANGE}

Semisupine bicycle exercise with breath-bybreath analysis of gas exchange was carried out on an electronically braked cycle ergometer (Ergo-metrics 900, Ergoline, Bitz, Germany). The workload was increased at a rate of $10 \mathrm{~W}$ per minute according to a ramp protocol until the symptom-limited maximum was reached. The patients were encouraged to exercise to an all-out effort before the stress test was begun. They were not pushed to exercise harder during the stress test. All exercise tests were stopped at the patient's request. Gas exchange was measured with an ergospirometry system (MCG Systems 2001, Medical Graphics, St Paul, USA).

The slope of the relation between oxygen uptake (ordinate) and workload (abscissa) was determined for each study by linear regression analysis. The initial $20 \mathrm{~W}$ were excluded from the analysis because of the kinetic lag in oxygen uptake after the onset of incremental work. ${ }^{12}$ This slope was proposed as a measure of the ability of the circulatory system to deliver oxygen to the working muscle and is referred to as oxygen uptake kinetics in this paper. ${ }^{13}$ The total ventilatory response to exercise, defined as the slope of the relation between minute ventilation (ordinate) and carbon dioxide production (abscissa), was also determined. ${ }^{14}$

\section{STATISTICAL ANALYSIS}

The change in peak oxygen uptake from prerandomisation control to week 16 was prospectively defined as the principal endpoint of this study. The analysis of the changes in measurements during the double blind treatment phase included all randomised patients, according to the intent to treat principle. No "within-group" analyses were carried out because such an approach is inappropriate. ${ }^{315}$ Baseline characteristics in the groups were compared by the WilcoxonMann-Whitney test. The changes from prerandomisation control to weeks $1,6,12$, and 16 were compared between the groups by the Wilcoxon-Mann-Whitney test for resting heart rate and blood pressure, body weight, peak oxygen uptake, ventilatory response to exercise and oxygen uptake kinetics. The changes in New York Heart Association functional class were compared between the groups by Uleman's test. A two-tailed $p$ value of $<0.05$ was regarded as significant. All values are given as mean ( 1 SD) unless otherwise specified.

\section{Results}

PATIENT CHARACTERISTICS AND CLINICAL COURSE

A total of 54 patients were recruited. Of these, five were withdrawn during the run-in phase. Forty seven of the 49 randomised patients had had radio-opaque ventriculo- 
Baseline characteristics of treatment groups

\begin{tabular}{|c|c|c|}
\hline & $\begin{array}{l}\text { Placebo } \\
(n=25)\end{array}$ & $\begin{array}{l}\text { Nitrate } \\
(n=24)\end{array}$ \\
\hline Age (y) & $57(8)$ & $57(8)^{\prime}$ \\
\hline $\begin{array}{l}\text { Sex: } \\
\text { Male } \\
\text { Female }\end{array}$ & $\begin{array}{r}23 \\
2\end{array}$ & 22 \\
\hline $\begin{array}{l}\text { NYHA functional class before randomisation (n): } \\
\text { II } \\
\text { III }\end{array}$ & $\begin{array}{l}10 \\
15\end{array}$ & $\begin{array}{l}11 \\
13\end{array}$ \\
\hline $\begin{array}{l}\text { Pre-study left ventricular ejection fraction (\%) } \\
\text { Peak oxygen uptake before randomisation }(\mathrm{ml} / \mathrm{min} / \mathrm{kg})\end{array}$ & $\begin{array}{l}28(8) \\
17 \cdot 4(3 \cdot 4)\end{array}$ & $\begin{array}{l}27(8) \\
17 \cdot 1(3 \cdot 5)\end{array}$ \\
\hline $\begin{array}{l}\text { Use of drugs before entry }(\mathrm{n}) \text { : } \\
\text { ACE inhibitors } \\
\text { Nitrates } \\
\text { Diuretics } \\
\text { Digoxin } \\
\text { Amiodarone }\end{array}$ & $\begin{array}{r}10 \\
14 \\
21 \\
8 \\
2\end{array}$ & $\begin{array}{r}9 \\
9 \\
19 \\
8 \\
3\end{array}$ \\
\hline $\begin{array}{l}\text { Diuretic therapy during randomised treatment } \\
\text { (number of patients (mean daily dose (1 SD) } \mathrm{mg} \text { ): } \\
\text { Frusemide } \\
\text { Piretanide } \\
\text { Xipamide } \\
\text { Hydrochlorothiazide } \\
\text { Serum creatinine before entry }(\mu \mathrm{mol} / \mathrm{l})\end{array}$ & $\begin{array}{c}7(46(25)) \\
12(5(1)) \\
1(40) \\
5(25(0)) \\
97(15)\end{array}$ & $\begin{array}{c}3(53(23)) \\
16(6(2)) \\
0(0) \\
5(25(0)) \\
95(17)\end{array}$ \\
\hline
\end{tabular}

graphy before the study. For the remaining two patients we had radionuclide ejection fraction data. Twenty four patients were randomised to receive nitrates and 25 to receive placebo. The two groups were similar at entry for demographic and functional variables, concomitant medications, and pre-treatment with converting enzyme inhibitors and nitrates (see table). Four patients of the nitrate-group and one patient of the placebo group were withdrawn. The reasons for withdrawal in the nitrate-group were angina of new onset in one (week 1), sustained ventricular tachycardia in two (weeks 1 and 6) and headache in one (week 2). The patient of the placebo group was excluded because of noncompliance (week 6). The study drug had to be reduced to half doses within the first 2 weeks after randomisation in two patients in the nitrate group because of headache.

\section{FUNCTIONAL CLASS, RESTING HEART RATE} AND BLOOD PRESSURE, AND BODY WEIGHT Functional class improved in the placebo and nitrate groups but the change from control to week 16 was not different between the groups (placebo group, mean decrease 0.50 ; nitrate group, mean decrease 0.45). Compared with the placebo group the nitrate group significantly $(p<0.05)$ increased resting heart rate at weeks 1,6 , and 16 (fig 1). There was no difference in the changes in resting blood pressure and body weight since randomisation between the two groups.

\section{EXERCISE TOLERANCE AND RESPIRATORY GAS EXCHANGE}

The groups did not differ at pre-randomisation examination with respect to peak oxygen uptake, oxygen uptake kinetics, and total ventilatory response to exercise. The increase in peak oxygen uptake tended to be greater in the placebo group than in the nitrate group after 12 weeks (mean increase from control: $1.1(2.7)$ v $0.0(2.7) \quad \mathrm{ml} / \mathrm{min} / \mathrm{kg}, \mathrm{p}<0.12)$ and 16 weeks $(1.7(3.0)$ v $0.3(2.6)$ $\mathrm{ml} / \mathrm{min} / \mathrm{kg}, \mathrm{p}<0.14)$ of randomised treatment. Figure 2 shows the time course of peak oxygen uptake. The changes in oxygen uptake kinetics and total ventilatory response to exercise were negligible in both groups.

LABORATORY STUDIES

The changes in blood chemistry were unremarkable. Specifically, combination therapy with captopril and isosorbide dinitrate had no adverse effect on renal function.

\section{Discussion}

The finding that the increase in exercise tolerance tended to be greater in the placebo group than in the nitrate group after 12 weeks and 16 weeks of treatment was unexpected. The trend in favour of placebo was noted whether the data were analysed according to the intent-to-treat principle or by evaluating only those patients who completed the 16 weeks of randomised treatment (week 12, $\mathrm{p}<0.22$; week $16, \mathrm{p}<0.28$ ).

The principal therapeutic goal in congestive heart failure is to improve survival. The effect of an intervention on exercise tolerance is only a surrogate endpoint. Recent experiences have shown that one must not extrapolate from the effect of an intervention on a surrogate endpoint, such as arrhythmia suppression, ejection fraction, or exercise tolerance, to the effect on mortality. ${ }^{16}$ The lack of effect of nitrates on exercise tolerance does not preclude a beneficial effect of nitrates on mortality when these agents are given as an adjunct to converting enzyme inhibitors. The effect of nitrate monotherapy on the survival of patients with chronic heart failure has never been investigated. Cohn et $a l^{6}$ showed
Figure 1 Changes in resting heart rate from prerandomisation control in the nitrate group and in the placebo group during the course of the study.

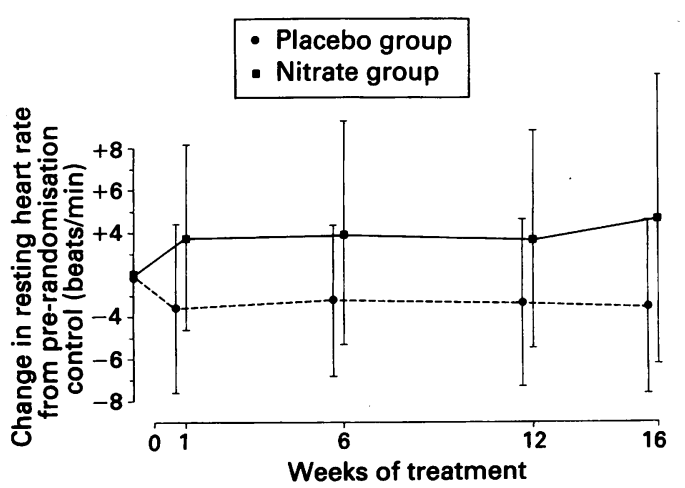

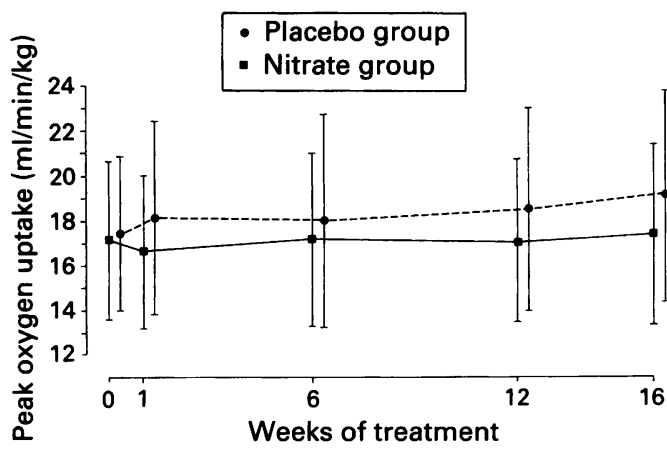

Figure 2 Peak oxygen uptake in the placebo group and in the nitrate group during the course of the study. 
that mortality was reduced more by a combination of isosorbide dinitrate and hydralazine than by placebo. It is not clear which of the two agents, isosorbide dinitrate or hydralazine or a specific drug interaction, caused the improvement of prognosis. Whether the addition of nitrates to a converting enzyme inhibitor confers long-term prognostic benefit is also unclear. A large trial of several thousands of patients followed for a few years would be required to answer this question. $\mathrm{Cohn}^{2}$ has pointed out that economic factors make such a trial unlikely. Many pharmaceutical companies produce nitrate preparations and it is unlikely that a single company would fund a large mortality trial because even a positive outcome would not increase their market share and profit to meet the high costs of such a study.

Combination therapy with captopril and nitrates has theoretical appeal so why did nitrates in this study not improve exercise tolerance? A nitrate-induced reflex activation of the sympathoadrenal axis or of the reninangiotensin system cannot explain the lack of effect of nitrates because intermittent treatment with nitrates does not activate these counterregulatory forces. ${ }^{17}$ Also the reninangiotensin system was blocked by captopril. Nitrates produced a slight increase in resting heart rate. It is interesting to speculate that nitrates reduced the antisympathetic cardiac effects of captopril, which might be one of the mechanisms by which converting enzyme inhibitors counteract left ventricular remodelling. Capewell et $a l^{18}$ showed that there was considerable chronic venodilatation in patients with heart failure on long-term treatment with captopril and that acute administration of glyceryl trinitrate did not potentiate venodilatation in these patients. Since venodilatation is claimed to be a major effect of nitrates in heart failure, the results of Capewell et al $^{18}$ may explain the long-term ineffectiveness of nitrates. In another study the addition of nitrates to captopril was of acute haemodynamic benefit in severe heart failure. ${ }^{19}$ Short-term haemodynamic benefit is, however, not an accurate predictor of long-term efficacy. Previous studies on the usefulness of this combination in patients with lesser degrees of heart failure are not available for comparison. Franciosa $e t a l^{20}$ showed that nitrates given as the sole vasodilatator in patients with heart failure reduced pulmonary capillary pressure at submaximal workloads but not at peak exercise. They presumed that this might allow the patient to carry out submaximal work in greater comfort. Cohn also proposed a dissociation between the effects during maximal and submaximal exercise. ${ }^{2}$ Our study showed no effect of nitrates on oxygen uptake kinetics and ventilatory response. This result does not accord with a differential therapeutic efficiency of nitrates at submaximal and maximal exercise in patients receiving captopril.

Of note are the dose regimens of captopril and nitrates. Previous trials on nitrates in chronic congestive heart failure suggested trends towards an increase in exercise tolerance but failed to demonstrate clearcu: evidence of benefit. ${ }^{415}$ The ideal dosing regimen of nitrates in heart failure is therefore unclear. We used a dose of $40 \mathrm{mg}$ isosorbide dinitrate because this target dose was also given in the earlier trials. In contrast to these studies, the drug was administered only twice daily with an interdosing interval of 16 hours to ensure nitrate responsiveness. ${ }^{17}$ So in our trial the question of whether captopril prevents nitrate tolerance in heart failure is not an issue. ${ }^{21-23}$ Captopril was given in a low dosage and only twice a day. Wilkes et al ${ }^{24}$ showed that twice daily dosage of captopril is effective in patients with mild heart failure. This dose regimen does not provide roundthe-clock inhibition of the plasma reninangiotensin system. We are not convinced that a more prolonged inhibition of the plasma converting enzyme is advantageous in patients with stable mild to moderate congestive heart failure in which the plasma renin activity is either normal or mildly increased because of diuretic therapy. ${ }^{25} 26$ Other neuroendocrine systems are activated early in the development of heart failure. ${ }^{26}$ Evidence is accumulating to suggest that the predominant sites of action of converting enzyme inhibitors in mild to moderate heart failure are tissuebound renin-angiotensin systems rather than the plasma system. ${ }^{27}$ Animal studies showed that a single dose of captopril inhibited the vascular and renal converting enzyme for more than 24 hours and that captopril caused a more prolonged inhibition of rat cardiac converting enzyme than enalapril. ${ }^{28}{ }^{29} \mathrm{It}$ is not at all clear, therefore, whether the so-called "long-acting" inhibitors are superior to captopril in patients with mild to moderate heart failure. Complete circadian inhibition of the plasma renin angiotensin system may be important in patients with severe heart failure. ${ }^{30}$ Theoretically, captopril might enhance the vasodilator action of nitrates by serving as donor of sulphydryl groups. The captopril dose used in this study may have provided only a small amount of sulphydryl groups so that this mechanism was probably not important.

Most earlier drug trials on heart failure included patients irrespective of the cause of left ventricular dysfunction so that a favourable drug effect in certain subgroups of patients might have been missed. We thought that this point was important when evaluating the effects of nitrates that act to increase coronary supply. Therefore, the study group was narrowly defined in terms of aetiology, pathophysiology, and degree of functional impairment. Our findings are not applicable to patients in severe heart failure or to patients with heart failure from other causes. In particular, they should not be extrapolated to coronary patients with heart failure who have angina. Captopril does not seem to be useful in this group. ${ }^{31}$

Cohn et al $^{32}$ suggested the combined use of a converting enzyme inhibitor and a different type of vasodilator to obtain maximum 
benefit in terms of survival and exercise tolerance. We found no evidence that the addition of nitrates to captopril improved exercise tolerance in coronary patients with mild to moderate heart failure and without evidence of ischaemia. Whether mortality is favourably affected when nitrates are added to a converting enzyme inhibitor is unclear. We therefore cannot recommend the use of nitrates as an adjunct to converting enzyme inhibitors. Less may be better than more in these patients.

We thank Schwarz Pharma AG for generously supplying our laboratory with captopril, isosorbide dinitrate, and placebo tablets.

1 Braunwald E. ACE inhibitors-a cornerstone of the treatment of heart failure. N Engl f Med 1991;325:351-3.

2 Cohn JN. Nitrates are effective in the treatment of chronic congestive heart failure: the protagonist's view. $A m \mathcal{F}$ Cardiol 1990;66:444-6.

3 Packer $M$. Are nitrates effective in the treatment of chronic heart failure? Antagonist's viewpoint. $A m \ngtr$ Cardiol 1990;66:458-61.

4 Franciosa JA, Goldsmith SR, Cohn JN. Contrasting immediate and long-term effects of isosorbide dinitrate on exercise capacity in congestive heart failure. $\mathrm{Am} \mathcal{f}$ Med 1980;69:559-66.

5 Leier CV, Huss P, Magorien RD, Unverferth DV. Improved exercise capacity and differing arterial and Improved exercise capacity and differing arterial and venous tolerance during chronic isosorbide dinitrate therapy

6 Cohn JN, Archibald DG, Ziesche S, et al. Effect of vasodilator therapy on mortality in chronic congestive heart failure. $N$ Engl F Med 1986;314:1547-52.

7 Palmer RMJ, Ferrige AG, Moncada S. Nitric oxide release accounts for the biological activity of endothelium-derived relaxing factor. Nature 1987;327:524-6.

8 Ikram H, Low CJS, Shirlaw T, Webb CM, Richards AM, Crozier IG. Antianginal, hemodynamic and coronary vascular effects of captopril in stable angina pectoris. vascular effects of captopril

9 van Gilst WH, de Graeff PA, de Leeuw MJ, Scholtens E, Wesseling $\mathbf{H}$. Converting enzyme inhibitors and the role of the sulphydryl group in the potentiation of exo- and endogenous nitrovasodilators. $\mathcal{F}$ Cardiovasc Pharmacol 1991;18:429-36.

10 van Gilst WH, Scholtens E, de Graeff PA, de Langen CDJ, Wesseling $H$. Differential influences of angiotensin converting-enzyme inhibitors on the coronary circulation. Circulation 1988;77(Suppl I):24-9.

11 Elborn JS, Stanford CF, Nicholls DP. Reproducibility of cardiopulmonary parameters during exercise in patients with chronic cardiac failure. The need for a preliminary test. Eur Heart 7 1990;11:75-81.

12 Hansen JE, Casaburi R, Cooper DM, Wasserman K. Oxygen uptake as related to work rate increment during cycle ergometer exercise. Eur $f$ Appl Physiol 1988;57: cycle ergo-5.

13 Itoh $H$, Taniguchi $K$, Koike A, Doi $M$. Evaluation of severity of heart failure using ventilatory gas analysis. Circulation 1990;81(Suppl II):31-7.

14 Buller NP, Poole-Wilson PA. Mechanism of the increased ventilatory response to exercise in patients with chronic heart failure. Br Heart f 1990;63:281-3.

15 Guyatt GH. The treatment of heart failure. A methodological review of the literature. Drugs 1986:32.538-68.

16 Yusuf $S$. Obtaining reliable information from randomized controlled trials in congestive heart failure and left ventricular dysfunction. In: Brachmann J, Dietz R, Kübler W, eds. Heart failure and arrhythmias. Berlin: Springer W, eds. Heart failure

17 Packer M. The clinical significance of nitrate tolerance in patients with chronic heart failure. Eur Heart $\mathcal{F} 1989$ 10(Suppl A):20-5

18 Capewell S, Taverner D, Hannan WJ, Muir AL. Acute and chronic arterial and venous effects of captopril in congestive cardiac failure. BMF 1989;299:942-5.

19 Halon DA, Rosenfeld T, Hardoff R, Lewis BS. Advantage of combined therapy with captopril and nitrates in severe congestive heart failure. Isr f $\mathrm{Med} S c i$ 1988;24: 664-70.

20 Franciosa JA, Cohn JN. Effect of isosorbide dinitrate on response to submaximal and maximal exercise in patients with congestive heart failure. Am $f$ Cardiol 1979;43:1009-14.

21 Dakak N, Makhoul N, Flugelman MY, et al. Failure of captopril to prevent nitrate tolerance in congestive heart failure secondary to coronary artery disease. $\mathrm{Am} \mathscr{f}$ Cardiol 1990;66:608-13.

22 Dupuis J, Lalonde G, Bichet D, Rouleau JL. Captopri does not prevent nitroglycerin tolerance in heart failure. Can f Cardiol 1990;6:281-6.

23 Katz RJ, Levy WS, Buff L, Wasserman AG. Prevention of nitrate tolerance with angiotensin converting enzyme inhibitors. Circulation 1991;83:1271-7.

24 Wilkes NPF, Barin E, Hoschl R, Stokes GS, Nelson GIC. Comparison of the immediate and long-term effects of captopril and isosorbide dinitrate as adjunctive treatment in mild heart failure. Br 7 Clin Pharmacol 1989; 28:427-34.

25 Dzau VJ, Colucci WS, Hollenberg NK, Williams GH Relation of the renin-angiotensin-aldosterone system to clinical state in congestive heart failure. Circulation 1981;63:645-51.

26 Francis GS, Benedict C, Johnstone DE, et al. Comparison of neurendocrine activation in patients with left ventricular dysfunction with and without congestive heart failure. A substudy of the studies of left ventricular dysfunction (SOLVD). Circulation 1990;82:1724-9.

27 Hirsch AT, Dzau VJ. Tissue renin-angiotensin systems in the pathophysiology of heart failure. In: Brachmann J Dietz R, Kübler W, eds. Heart failure and arrhythmias. Berlin: Springer Verlag, 1990, 33-42.

28 Cushman DW, Wang FL, Fung WC, Harvey CM DeForrest JM. Differentiation of angiotensin-converting enzyme (ACE) inhibitors by their selective inhibition of enzyme (ACE) inhibitors by their selective inhibition of ACE in physiologically im

29 Cohen ML, Kurz KD. Angiotensin converting enzyme inhibition in tissues from spontaneously hypertensive rats after treatment with captopril or MK-421. F Pharmacol Exp Ther 1982;220:63-9.

30 Pouleur H, Rousseau MF, Oakley C, Ryden L for the Xamoterol in Severe Heart Failure Study Group. Difference in mortality between patients treated with captopril or enalapril in the xamoterol in severe heart failure study. Am 7 Cardiol 1991;68:71-4.

31 Cleland JGF, Henderson E, McLenachan J, Findlay IN, Dargie HJ. Effect of captopril, an angiotensin-converting enzyme inhibitor, in patients with angina pectoris ing enzyme inhibitor, in patients with angina pecto

32 Cohn $J$, Johnson G, Ziesche $S$, et al. A comparison of enalapril with hydralazine-isosorbide dinitrate in the treatment of chronic congestive heart failure. $N$ Engl $\mathcal{F}$ Med 1991;325:303-10. 